Working Paper 03-23

Economics Series 03

April 2003
Departamento de Economía Universidad Carlos III de Madrid

Calle Madrid, 126

28903 Getafe (Spain)

Fax (34) 916249875

\title{
DOES WEALTH EXPLAIN BLACK-WHITE DIFFERENCES IN EARLY EMPLOYMENT CAREERS? *
}

\author{
Sílvio Rendon ${ }^{1}$
}

\begin{abstract}
This paper inquires on the effect of initial wealth in racial differences in early employment careers. I set up a dynamic model in which people simultaneously search for a job and accumulate wealth, and fit it to data from the National Longitudinal Survey (1979-cohort). With the recovered behavioral parameters, I perform regime changes consisting in giving blacks (i) the initial wealth distribution, and (ii) the arrival rates and wage offer distribution of whites. These counterfactual experiments show that initial wealth has a modest influence in the black-white difference in early employment careers in comparison with labor market variables.
\end{abstract}

Keywords: Job search, asset accumulation, borrowing constraints, consumption, unemployment, estimation of dynamic structural models.

JEL Classification: C33, E21, E24, J64.

${ }^{1}$ Universidad Carlos III de Madrid and Universitat Pompeu Fabra, Spain;

E.mail: srendon@eco.uc3m.es

* Updates of this paper can be downloaded from http://www.eco.uc3m.es/ srendon.

I thank Chris Flinn, Ken Wolpin, and Wilbert van der Klaauw for their suggestions to a previous version of this paper. I also thank Núria Quella for helpful comments. Financial support of the Spanish Ministry of Science and Technology (Grant SEC 2001-0674) is gratefully acknowledged. The usual disclaimer applies. 


\section{Introduction}

The last decade has witnessed a growing interest in the black-white wealth gap. Historically, income disparity between blacks and whites has narrowed down (Smith \& Welch 1989), nevertheless, wealth disparity remains large. While blacks earn between $50 \%$ and $64 \%$ of whites' income, blacks' wealth only represents between $12 \%$ and $20 \%$ of whites' wealth (Blau \& Graham 1990, Wolff 1994, Menchik \& Jianakoplos 1997, Oliver \& Shapiro 1997). Recent studies on racial differences in wealth have attempted to explain gaps in wealth levels and growth rates by differences in income, education, and patterns of marriage and fertility (Gittleman \& Wolff 2003, Altonji \& Doraszelski 2001). This paper's concern is whether causality also works in the opposite direction, that is, whether initial wealth disparity explains black-white differences in employment rates and wages for High School graduates. I estimate a dynamic model of wealth accumulation and job search and find that initial wealth plays a modest role in explaining racial differences in early employment careers, although initial wealth is an important determinant of the observed racial wealth gap.

With imperfect capital markets, wealth affects job search outcomes by allowing: wealthier agents to search longer and obtain higher wages. This effect is formalized by a utility-maximizing job search model where agents' reservation wages depend positively on their wealth levels. Thus, wealth accumulation is part of an optimal job search strategy in which unemployed agents run down their wealth to maintain their consumption, and employed agents accumulate wealth to hedge against future unemployment spells and to move to better paid jobs. It is clear that skill gaps can be an important determinant of the black-white wage differences.(Neal \& Johnson 1996). Consequently, to abstract from the effect of wealth in employment outcomes through schooling, I restrict the analysis to individuals of the same level of schooling.

The empirical strategy consists of recovering the behavioral parameters of the model applying the method surveyed by Rust (1988) and Eckstein \& Wolpin (1989). I use the numerical solution to the joint job search and consumption problem to con- 
struct a likelihood function for the observed paths of wealth, wages and employment, which is maximized over the behavioral parameters. Under this strategy, also used by Wolpin (1992) to study black-white employment differences, one can perform regime changes that take explicitly into account the often overlooked distinction between permanent and transitory income fluctuations. I study the effects on wages of two regime changes consisting in assigning blacks: (i) the initial wealth distribution of whites, and (ii) the arrival rates and the wage offer distribution of whites. The first regime change produces an important initial effect in blacks' wages that disappears very rapidly: at the 40th quarter after graduation, a benchmark for making the blackwhite outcome comparison, the average wage of blacks stays unaffected at a $75 \%$ of the average wage of whites. Nevertheless, because of this change, the wealth of blacks increases from being $40 \%$ of the wealth of whites to being $52 \%$. The second regime change has a more substantial effect on wages: the average wage of blacks rises from $75 \%$ to $102 \%$ of the average wage of whites. In spite of this increase, the black-white wealth gap does not disappear, although it narrows down: the wealth of blacks in the 40th quarter after graduation increases from $40 \%$ to $69 \%$ of the wealth of whites. Labor market variables such as wage offer distributions and arrival rates, and not initial assets, are responsible for most of the observed differences in employment careers.

The remainder of the paper is organized as follows. The next section explains the data source, the National Longitudinal Survey of Labor Market Experience Youth Cohort (NLSY), the selection of the sample and the descriptive statistics; Section 3 describes the model and discusses the maximum likelihood estimation procedure; Section 4 presents the results of the estimation, and Section 5 presents regime changes based on the estimated parameters of the model. The main conclusions of the paper are summarized in Section 6 


\section{Data}

\subsection{Sample Selection}

The National Longitudinal Survey of Labor Market Experience Youth Cohort (NLSY) contains data on household composition, military experience, school enrollment, and a week by week accounting of employment status, hourly wages, hours worked, and employers. An individual's complete weekly work history can be constructed from 1978 until 1993. Respondents whose employment histories started before 1978, i.e., those born before 1961, are dropped from the sample, because it is impossible to construct a complete employment history for them. The final sample consists of 212 white and 158 black high school male graduates born after December 31, 1960, who never went to college nor had any type of military experience. White males were taken from the core sample; black males were selected from the core and from the supplemental sample. Wolpin (1992) and Rendon (2002) also used this selection, aimed to include those individuals whose behavior is well described with a searchtheoretic framework without a decision to join the military.

To make the estimation tractable, I aggregate the data into quarters. Each individual's reported last week of school enrollment is assigned to its corresponding calendar quarter; employment history is defined to start in the quarter thereafter. An individual is considered to be employed if he works 20 or more hours during the first week of the quarter; any other job held during the quarter is ignored. Otherwise he is reported as "unemployed" for that quarter. Reasons for leaving a given employer are classed as layoffs or quits. Individuals returning to work for their old employers are considered as having taken new jobs. The quarterly wage related to that job is

the wage of the first week of the quarter in 1985 dollars times 13 . The Consumer Price Index is used to deflate nominal values into real amounts.

Annual data on the market value of wealth are only available for years 1985 until 1993, with the exception of year 1991; this information is assigned to the calendar 
quarter in which the interview took place, leaving all other quarters blank. Wealth consists of residential property, financial assets, business assets, vehicles and other assets (like jewelry or furniture), each net of debts. All these components are computed at their "market value", defined by the NLSY as the amount the respondent would reasonably expect someone else to pay if the particular asset were sold today in its present condition. Any debt owed for any of these components is subtracted from the total value of each component. Because wealth is thought of as a store of value, these components are treated as being equally liquid, meaning that wealth is defined as the sum of its different components. If the respondent does not report at least one of them, the wealth variable is reported as not available.

\subsection{Descriptive Statistics}

Table 1 shows the evolution of employment rates and transitions, wealth and wages for three years after High School graduation. From year 3 to year 9 after graduation, the fraction of whites who are unemployed decreases from $18 \%$ to $9 \%$, while the corresponding percentage for blacks decreases from $34 \%$ to $20 \%$. In the same period, whites increase their wealth from $\$ 6,023$ to $\$ 13,329$, whereas blacks increase their wealth from $\$ 1,226$ to $\$ 5,223$, that is, the black-white ratio of average wealth increases from $20 \%$ to $39 \%$. The percentage of people with more than $\$ 10,000$ increases from $19 \%$ to $43 \%$ for whites, and from $1 \%$ to $15 \%$ for blacks. Average wages of whites increase from $\$ 3,363$ to $\$ 4,552$; average wages of blacks increase from $\$ 3,104$ to $\$ 3,739$, meaning that the black-white ratio of average wage decreases from $92 \%$ to $82 \%$. It is clear that wealth accumulation does accompany the increase in labor market activity that occurs after these individuals graduate from High School and that a reduction in the racial wealth gap is associated with a widening of the racial wage gap.

[Table 1 here] 
Table 2 shows the relationship between the level and the composition of wealth by race group and years of working experience. These patterns in the composition of wealth coincide with those shown in other studies (Jianakoplos, Menchik \& Irvine 1989, Blau \& Graham 1990, Smith 1995). Wealthier people in both groups tend to have a higher proportion of their wealth in the form of residential property, business, farms or other form of property. Among white individuals with no more than 6 years of employment history, those with no more than $\$ 10,000$ have only $7 \%$ of their wealth in residential property. The corresponding percentage of blacks is substantially lower: $2 \%$. The percentages for those with more than $\$ 30,000$ are $23 \%$ for whites and $15 \%$ for whites. This relationship between wealth and proportion of wealth held as residential property is maintained 6 years after graduation. There is also a fairly clear positive correlation between the percentage of business property and wealth. However, at the same wealth level blacks systematically exhibit a lower percentage of their wealth in business property than whites, denoting a relative absence of blacks' owned businesses (Fairlie 1999, Fairlie \& Meyer 2000). The proportion of wealth in the form of vehicles shows a very clear negative correlation with wealth. This trend is similar for both race groups and does not seem to change significantly with the increase in the number of years after graduation. Financial assets are the most liquid component of wealth, but they show no clear link with the level of wealth.

[Table 2 here]

Table 3 shows the average wealth by wage levels, years after graduation and race group. It shows that agents with higher wages tend to have a higher level of wealth. No more than 6 years after graduation, whites with wages lower than $\$ 2,000$ have an average wealth of $\$ 1,368$, whereas whites with wages over $\$ 6,000$ have an average wealth of $\$ 8,744$. The corresponding amount of wealth of blacks for the same wage brackets are, respectively, $\$ 730$ and $\$ 6,115$. These descriptive statistics show the existence of a link between labor market aspects and wealth accumulation. Differences in 
wages and in wealth between the two race groups are both noteworthy and persistent over time.

[Table 3 here]

\section{Model}

In this section I describe a model of wealth accumulation and job search under borrowing constraints. I use the solution to this model to construct a likelihood function for the observed transitions of employment, wages and wealth, which I maximize over the behavioral parameters of the theoretical model. The numerical solution of the model and the computation of the likelihoof function are both based in Rendon (2002).

\subsection{Job Search and Consumption}

An individual who maximizes his expected utility of consumption over $T$ quarters can be employed or unemployed. While unemployed he receives, with probability $\lambda^{e}$, one wage offer $x$ drawn from the known wage offer distribution $F(\cdot), x \in(\underline{w}, \bar{w}), 0<$ $\underline{w}<\bar{w}<\infty$. An unemployed individual becomes employed if he receives and accepts a wage offer; otherwise he remains unemployed. Transitions from unemployment are illustrated in the following scheme:

[Figure 1 here]

While employed, an individual can be laid off with probability $\theta$ and receive a new wage offer with probability $\lambda^{e}$, drawn from the same distribution $F(\cdot)$. If he is not laid off and receives a job offer, he can accept it and switch to a new job, reject it and stay in the current job, or reject it and quit to unemployment. If he is not laid off 
and does not receive a job offer, he has to decide between staying in his current job or quitting to unemployment. If he is laid off, he can still receive a job offer; accepting it means switching to a new job; rejecting it means becoming unemployed. If a person is laid off and does not receive any offer, he does not have any other option than to become unemployed. The possible transitions from being employed are shown below.

[Figure 2 here]

When unemployed the agent receives transfers $b$, which include non-labor income, such as family transfers and unemployment compensation net of search costs. At each period, given his employment state and his wealth $A_{t}$, the agent determines his consumption $C_{t}^{u}$ and $C_{t}^{e}$, and thereby his wealth for the next period $A_{t+1}^{u}$ and $A_{t+1}^{e}$. Initial wealth is inherited and final wealth is zero. The rate of return is $r$ and is constant; the subjective discount factor is $\beta \in(0,1)$. Agents can save freely, but borrowing is restricted so that current wealth cannot be lower than a time-dependent level $B_{t}$. In a free capital market people can borrow up to the level that they can pay back with probability one, which is determined by the present discounted value of the lowest possible income level $b$ : $\widetilde{B}_{t}=-\sum_{s=t}^{T} b \frac{1}{(1+r)^{T-s}}$.

With a utility function $U(\cdot)$ satisfying the Inada condition, $\lim _{C \rightarrow \mathbf{0}} U^{\prime}(C)=\infty$ , any constraint $B_{t}<\widetilde{B}_{t}$ is redundant, so that potentially binding constraints are $B_{t}>\widetilde{B}_{t}$. Let $s$ measure the tightness of the borrowing constraint as a fraction of $\widetilde{B}_{t}$, then the lower bound on wealth is $B_{t}=s \widetilde{B}_{t}, s \in[0,1]$.

When unemployed, expected lifetime utility at time $t V_{t}^{u}$ depends on wealth $A_{t}$ :

$$
\begin{aligned}
V_{t}^{u}\left(A_{t}\right)= & \max _{A_{t+1}^{u} \geq B_{t+1}}\left\{U\left(A_{t}+b-\frac{A_{t+1}^{u}}{1+r}\right)\right. \\
& \left.+\beta\left[\lambda^{u} \int \max \left[V_{t+1}^{e}\left(A_{t+1}^{u}, x\right), V_{t+1}^{u}\left(A_{t+1}^{u}\right)\right] d F(x)+\left(1-\lambda^{u}\right) V_{t+1}^{u}\left(A_{t+1}^{u}\right)\right]\right\} .
\end{aligned}
$$


When employed, expected lifetime utility $V_{t}^{e}$ at time $t$ depends on wealth $A_{t}$ and wage $w$ :

$$
\begin{aligned}
V_{t}^{e}\left(A_{t}, w\right)= & \max _{A_{t+1}^{e} \geq B_{t+1}}\left\{U\left(A_{t}+w-\frac{A_{t+1}^{e}}{1+r}\right)\right. \\
& +\beta\left[( 1 - \theta ) \left(\lambda^{e} \int \max \left[V_{t+1}^{e}\left(A_{t+1}^{e}, x\right), V_{t+1}^{e}\left(A_{t+1}^{e}, w\right), V_{t+1}^{u}\left(A_{t+1}^{e}\right)\right] d F(x)\right.\right. \\
& \left.+\left(1-\lambda^{e}\right) \max \left[V_{t+1}^{e}\left(A_{t+1}^{e}, w\right), V_{t+1}^{u}\left(A_{t+1}^{e}\right)\right]\right) \\
& \left.\left.+\theta\left(\lambda^{e} \int \max \left[V_{t+1}^{e}\left(A_{t+1}^{e}, x\right), V_{t+1}^{u}\left(A_{t+1}^{e}\right)\right] d F(x)+\left(1-\lambda^{e}\right) V_{t+1}^{u}\left(A_{t+1}^{e}\right)\right)\right]\right\} .
\end{aligned}
$$

The solution to these equations consists of two policy rules $A_{t+1}^{u}\left(A_{t}\right)$ and $A_{t+1}^{e}\left(A_{t}, w\right)$, and of a reservation wage $w_{t}^{*}\left(A_{t}\right)=\left\{w \mid V_{t}^{u}\left(A_{t}\right)=V_{t}^{e}\left(A_{t}, w\right)\right\}$. These solutions are no analytical but numerical, that is, one needs to assume specific functional forms for the utility and the wage offer distribution function: a constant relative risk aversion (CRRA) utility function $U(C)=\frac{C^{1-\gamma}-1}{1-\gamma}$, where $\gamma$ is the coefficient of risk-aversion, and a $\log$-normal wage offer distribution $\ln x \sim N\left(\mu, \sigma^{2} \mid \underline{w}, \bar{w}\right), 0<\underline{w}<\bar{w}<\infty$. Then the model is solved recursively on a discretized state space. As done by Wolpin (1992), the estimation is made tractable assuming that the individual solves the DP problem using longer period lengths for the more distant future value functions.

\subsection{Likelihood function}

For each parameter set I compute the policy rules that solve the dynamic programming problem, and use them to construct probability statements for each transition in employment, wages, and wealth. The resulting function relates a parameter set to a likelihood value. The estimation is thus a maximum likelihood procedure in which the estimates are the behavioral parameters, the maximizers of this function.

The observed variables are $Z_{i t}=\left\{A_{i t}^{o b s}, w_{i t}^{o b s}, d_{i t}, l_{i t}\right\}$, that is, wealth, wages, employment status, unemployed or employed: $d=\{u, e\}$, and layoffs, $l=0$ (quit) or $l=1$ (layoff). Because the model does not predict a true initial level of wealth, the 
estimation starts at period $t_{0}$, defined as the period when wealth is first observed. This implies that data between 1978 and 1985 are not used in this estimation. The log-likelihood function is the sum of the individuals' log-likelihood, which is the density for observing a particular sequence of wealth, wages, and employment transitions, conditional on the first observation and on the parameters $\Theta$ :

$$
\ln \mathcal{L}(\Theta)=\sum_{i=1}^{N} \ln \mathcal{L}_{i}\left(\left\{Z_{i t}\right\}_{t=t_{0}+1}^{T_{i}} \mid Z_{i t_{0}} \Theta\right)
$$

The individuals' likelihood contribution can be computed as the product of the conditional and the marginal densities for each employment transition, denoted by $g_{t}\left(A_{t+1}, w_{t+1} \mid A_{t}, w_{t}\right)$. The subscript for the individual $i$, the parameter vector $\Theta$, employment status (expressed by a wage equal to zero), and layoffs are dropped from the notation. There are five possible employment transitions:

1. Unemployment to unemployment:

$$
g_{t}\left(A_{t+1}, 0 \mid A_{t}, 0\right)=\lambda^{u} F\left[w_{t}^{*}\left(A_{t+1}\right)\right]+\left(1-\lambda^{u}\right) \text {, if } A_{t+1}=A_{t+1}^{u}\left(A_{t}\right) .
$$

2.Unemployment to employment:

$$
g_{t}\left(A_{t+1}, w_{t+1} \mid A_{t}, 0\right)=\lambda^{u} f\left(w_{t+1}\right) \text {, if } w_{t+1} \geq w_{t+1}^{*}\left(A_{t+1}\right) \text { and } A_{t+1}=A_{t+1}^{u}\left(A_{t}\right)
$$

3. Employment to unemployment:

$$
\begin{aligned}
\text { Layoffs, } l & =1: \quad g_{t}\left(A_{t+1}, 0 \mid A_{t}, w_{t}\right)=\theta\left[\lambda^{e} F\left(w^{*}\left[A_{t+1}\right]\right)+\left(1-\lambda^{e}\right)\right], \\
\text { if } A_{t+1} & =A_{t+1}^{e}\left(A_{t}, w_{t}\right) ; \\
\text { Quits, } l & =0: \quad g_{t}\left(A_{t+1}, 0 \mid A_{t}, w_{t}\right)=(1-\theta)\left[\lambda^{e} F\left(w^{*}\left[A_{t+1}\right]\right)+\left(1-\lambda^{e}\right)\right], \\
\text { if } w_{t+1}^{*}\left[A_{t+1}\right] & >w_{t} \text { and } A_{t+1}=A_{t+1}^{e}\left(A_{t}, w_{t}\right) ;
\end{aligned}
$$

4. Keep employer:

$$
\begin{aligned}
g_{t}\left(A_{t+1}, w_{t} \mid A_{t}, w_{t}\right) & =(1-\theta)\left[\lambda^{e} F\left(w_{t}\right)+\left(1-\lambda^{e}\right)\right] \\
\text { if } w_{t} & \geq w_{t}^{*}\left[A_{t+1}\right] \text { and } A_{t+1}=A_{t+1}^{e}\left(A_{t}, w_{t}\right) ;
\end{aligned}
$$




\section{Change employer:}

Layoffs, $l=1: \quad g_{t}\left(A_{t+1}, w_{t+1} \mid A_{t}, w_{t}\right)=\theta \lambda^{e} f\left(w_{t+1}\right)$, if $w_{t+1} \geq w_{t+1}^{*}\left[A_{t+1}\right]$ and $A_{t+1}=A_{t+1}^{e}\left(A_{t}, w_{t}\right)$;

Quits, $l=0: \quad g_{t}\left(A_{t+1}, w_{t+1} \mid A_{t}, w_{t}\right)=(1-\theta) \lambda^{e} f\left(w_{t+1}\right)$, if $w_{t+1} \geq \max \left(w_{t}, w_{t}^{*}\left[A_{t+1}\right]\right)$ and $A_{t+1}=A_{t+1}^{e}\left(A_{t}, w_{t}\right)$;

where $g_{t}\left(A_{t+1}, w_{t+1} \mid A_{t}, w_{t}\right)=0$, if the corresponding condition is not satisfied. I introduce a measurement error in wealth and in wages to make the estimation feasible. Observed wealth and observed wages are defined as the model's predicted level plus a measurement error: $A_{t}^{o b s}=A_{t}+\varepsilon_{A}, \ln w_{t}^{o b s}=\ln w_{t}+\varepsilon_{w}$, where $\varepsilon_{A}$ and $\varepsilon_{w}$ are normally distributed, with zero mean and standard deviation $\sigma_{A}$ and $\sigma_{w}$, respectively. It is convenient to define the following densities:

$$
\begin{aligned}
& h_{A}\left(A_{t}^{o b s}, A_{t}\right)=\frac{1}{\sigma_{A}} \phi\left(\frac{A_{t}^{o b s}-A_{t}}{\sigma_{A}}\right) \\
& h_{w}\left(w_{t}^{o b s}, w_{t}\right)=\frac{1}{\sigma_{w}} \phi\left(\frac{\ln w_{t}^{o b s}-\ln w_{t}}{\sigma_{w}}\right) .
\end{aligned}
$$

where $h_{A}\left(A_{t}^{\text {obs }}, A_{t}\right)=1$, if wealth is not observed in the corresponding quarter. In the theoretical model wealth and wages depend on past wealth and wages, implying that there are several sequences of true wealth and wages that can produce the observed sequence. The density for the whole observable sequence is then the integral of the product of the conditional densities over all transitions, conditional on the first observation at period $t_{0}$ :

$\mathcal{L}\left(\left\{Z_{t}\right\}_{t=t_{0+1}}^{T} \mid Z_{t_{0}} \Theta\right)=\int \cdots \int \prod_{t=t_{0}}^{T} h_{A}\left(A_{t}^{o b s}, A_{t}\right) h_{w}\left(w_{t}^{o b s}, w_{t}\right) g_{t}\left(A_{t}, w_{t} \mid A_{t-1}, w_{t-1}\right) d A_{t} d w_{t}$.

where $g_{0}\left(A_{t_{0}}, w_{t_{0}} \mid A_{t_{0-1}}, w_{t_{0-1}}\right)=1$. This likelihood function is computed exploiting the discretization of the continuous variables performed to solve the DP problem; therefore, the multiple integrations become summations, whose computation is simplified by an iterative procedure. The parameters to estimate are $\Theta=\left\{b, \lambda^{u}, \lambda^{e}, \theta\right.$, 
$\left.\mu, \sigma, \gamma, s, \sigma_{A}, \sigma_{w}\right\}$. The interest rate $r$ and the discount factor $\beta$ are fixed at 0.015 and at 0.98 , respectively. The algorithm used to maximize this likelihood function does not require derivatives.

\section{Estimation Results}

In this section I discuss the parameter estimates for the two race groups, explain the computation of their initial wealth distribution, and compare actual and fitted variables: hazard rates at the first unemployment spell and trajectories for all observed variables, both graphically and numerically.

\subsection{Behavioral Parameters}

The two sets of maximum likelihood estimates and the corresponding asymptotic standard errors are reported in Table 4. Transfers while unemployed are $\$ 400$ for whites and $\$ 490$ for blacks.

[Table 4 here]

Whites have a higher probability of getting a wage offer when unemployed than blacks, but a lower probability of getting a wage offer when employed. The layoff rate is $4.42 \%$ for whites and $5.39 \%$ for blacks. The mean and the standard deviation of the log-wage offer distribution are 7.17 and 0.98 for whites and 7.09 and 0.78 for blacks, respectively. As shown in Figure 3, these estimates show that the wage offer distribution of whites stochastically dominates that of blacks.

[Figure 3 here] 
These estimates imply a more favorable labor market environment for whites than for blacks. The estimated coefficient of risk-aversion $\gamma$ is 1.3 for whites and 1.1 for blacks. The parameter $s$ capturing the tightness of the borrowing constraints is 0.11 for whites and 0.19 for blacks. A looser borrowing constraint for blacks than for whites can be caused by the fact that, in general, blacks have less wealth than whites at all times. To mimic this observed feature of the data, the model is forced to admit a lower level of wealth for blacks.

These parameters produce reservation wages that are increasing in wealth, as shown in Figure 4. Except for low levels of wealth, whites have higher reservation wages than blacks.

[Figure 4 here]

These data, especially wealth data, are very noisy; accordingly, measurement errors in both wages and wealth are high. For wealth the standard deviation of the measurement error is 16,180 for whites and 10,245 for blacks; for log-wages it is 0.58 for whites and 0.58 for blacks. Asymptotic standard errors are calculated using the OPG estimator and provided in parentheses; they are in general small.

\subsection{Initial wealth distribution}

The estimation was conditioned on the individuals' first wealth observation, meaning that data on employment status and wages from 1978 to 1985 have not been used in the likelihood function. These data can be used to estimate the initial wealth distribution. Let $Z_{0}=\left\{A_{0}, 0,0,0\right\}$, that is, agents are unemployed with wealth level $A_{0}$ when they graduate from High School. Thus, the likelihood of observing the data 
for one individual from period 1 until period $t_{\mathbf{0}}$, conditional on wealth level $A_{0}$ is

$\mathcal{L}\left(\left\{Z_{t}\right\}_{t=1}^{t_{0}} \mid A_{\mathbf{0}}, \Theta\right)=\int \ldots \int \prod_{t=1}^{t_{0}} h_{A}\left(A_{t}^{o b s}, A_{t}\right) h_{w}\left(w_{t}^{o b s}, w_{t}\right) g_{t}\left(A_{t}, w_{t} \mid A_{t-1}, w_{t-1}\right) d A_{t} d w_{t}$

This function is computed in a similar way to the likelihood function described in Section 4. Hence, the density function of initial wealth for each individual is

$$
p\left(A_{0} \mid \Theta\right)=\frac{\mathcal{L}\left(\left\{Z_{t}\right\}_{t=1}^{t_{0}} \mid A_{0}, \Theta\right)}{\int \mathcal{L}\left(\left\{Z_{t}\right\}_{t=1}^{t_{0}} \mid A, \Theta\right) d A}
$$

[Figure 5 here]

Figure 5 illustrates the resulting cumulative distribution for white and black individuals. It is clear that the whites' distribution dominates the blacks' distribution, except for one segment. With the recovered initial wealth distributions and the policy rules computed at the parameter estimates, assuming that individuals are unemployed when they graduate from High School, I generate simulated career paths for 10 draws for each individual in each race subsample. From these simulated data, I compute the hazard rate at the first unemployment spell and build a period-specific predicted choice distribution.

\subsection{Hazard Rate at the First Unemployment Spell}

Figure 6 and Figure 7 show the actual and the predicted hazard rates for the first unemployment spell. For both groups, the actual hazard rate presents negative duration dependence at the beginning of the spell and positive duration dependence at the end of the spell, that is, the hazard rate is U-shaped. However, whites have a higher hazard rate with steeper negative duration dependence than blacks. These patterns are reproduced by the predicted hazard rates, but with some overprediction in levels. 
For whites the predicted hazard rate follows closely the actual hazard rate at the beginning of the spell, but overpredicts it from the fifth quarter after graduation on. For blacks, the predicted hazard is relatively constant at 0.3 . In this model the initial wealth distribution plays a crucial role for reproducing negative duration dependence. In the model, conditional on one initial wealth level, hazard rates are increasing over time: people reduce their wealth position while unemployed, so that reservation wages decline and hazard rates increase. Initially, as poor individuals, who exhibit high hazard rates, are first to exit unemployment, the average hazard rate goes down, that is, the selection effect dominates over the increasing hazard rate at each wealth level. Once poor agents have exited and unemployment and wealthy agents remain unemployed, average hazard rates become increasing. Because blacks have a lower and more concentrated wealth distribution, the selection effect is not strong enough to fully capture the observed negative duration dependence in hazard rates.

[Figure 6 and Figure 7 here]

\subsection{Graphical Comparison}

Figure 8 reports the paths for actual and predicted employment states, employment transitions, average wealth and average wages by quarters after graduation. The model replicates relatively well the unemployment rate (Figures $8 \mathrm{a}$ and 8b), the transition from unemployment to employment (Figures 8c and 8d), the transition from employment to unemployment (Figures $8 \mathrm{e}$ and 8f) and the percentage of layoffs in the transitions from employment to unemployment (Figures $8 \mathrm{i}$ and 8j). However, it clearly underpredicts the percentage of people that change employers (Figures $8 \mathrm{~g}$ and 8h) and the percentage of layoffs in the transitions from one employment to another (Figures 8k and 81).

[Figure 8 here] 
Figures $8 \mathrm{~m}$ and $8 \mathrm{n}$ show that the model is able to mimic well the basic trend in wealth accumulation; however, as shown in Figures 50 and 8p, it overpredicts wages. Predicted average wages start higher than actual ones and grow slower than their actual counterpart. This discrepancy may occur because, in the theoretical model, wage growth is achieved only by switching to better paid jobs, whereas in the data wages can increase while on the job. Measurement errors in wages and not the theoretical model account for wage increases while working for the same employer. In spite of this simplification, which seems to produce the overprediction in wages, the model is able to replicate the tendency of wages to increase, so that the distance between predicted and actual average wages goes down over time. These graphs are illustrative of the success of the model in replicating the data; a more accurate assessment needs goodness of fit tests.

\subsection{Goodness of Fit Tests}

To assess whether the parameter estimates capture the essential features of the data, I compare the observed and the predicted choice distributions of employment, wealth, and wages. Goodness of fit tests evaluate whether the cell-by-cell distribution of the data can be produced by the theoretical model at the estimated parameters. Let

$\chi^{2}=\Sigma_{j=1}^{J} \frac{\left(n_{j t}-\hat{n}_{j t}\right)^{2}}{\hat{n}_{j t}}$, where $n_{j t}$ is the actual number of observations of choice $j$ at time $t$, and $\hat{n}_{j t}$ the model predicted counterpart. $J$ is the total number of possible choices. This statistic has an asymptotic $\chi^{2}$ distribution with $J-1$ degrees of freedom .

[Table 5 and Table 6 here]

Table 5 and Table 6 are a summary of the actual and predicted distributions of all variables for years 3,6 , and 9 after graduation and for both race groups. As in the graphical comparisons, lower distances between the model and the data are attained for employment status, transitions from unemployment, and layoffs in the transitions 
from employment to unemployment. In these three distributions, and especially in year 6 , the $\chi^{2}$ statistic falls below the critical value at a $5 \%$ of significance. However, the choice distributions of the transitions from employment and of the transitions of layoffs while changing employer do not pass the $\chi^{2}$ test. The model does a better job in approximating the actual distribution of wealth, but not of wages, as already seen in the graphical comparisons. Notice, however, that the model's fit for the black-white wage ratio of wages is better than the one in levels. For wealth the $\chi^{2}$ statistic tends to fall below the critical value at a $5 \%$ of significance. For wages the null hypotheses, i.e. that the data and the simulations come from the same distribution, is rejected, although the $\chi^{2}$ statistic goes down over time, reflecting the convergence of actual and predicted wages discussed in the previous subsection.

\section{$5 \quad$ Policy Experiments}

In this section I perform some regime changes and report them in Table 7 . The first column shows selected predicted variables for the subsample of blacks, the second column reports those same variables when blacks start off their careers with the initial wealth distribution of whites, the third column shows the effects of blacks' outcomes if they had whites' arrival rates and the whites' wage offer distribution, and the fourth column shows the prediction for the whites' subsample.

[Table 7 here]

The first experiment is a simulation of blacks variables if they had the initial wealth distribution of whites and it is reported in Table 7, column 2. Given that the initial wealth distribution of whites dominates that of blacks, both the duration of the first unemployment spell and the first accepted wage of blacks increase slightly. Later, the original and the counterfactual amounts tend to converge; forty quarters 
after graduation the increase in wages practically disappears, although wealth is still substantially higher: the black-white wage ratio stays unaffected at $75 \%$ whereas the black-white wealth ratio increases from $40 \%$ to $52 \%$. This result is in line with previous research (Menchik \& Jianakoplos 1997), which shows that inheritances account for a range of between $10 \%$ and $20 \%$ in differences in household wealth.

The second experiment simulates blacks outcomes if they had the labor market parameters of whites and is reported in Table 7, column 3. For blacks the unemployment rate decreases and the average wage increases. The first accepted wage of blacks increases from $\$ 3,324$ to $\$ 4,322$, which is higher than that of whites, $\$ 3,843$; forty quarters after graduation average wages increase from $\$ 4,176$ to $\$ 5,633$, slightly higher than those of whites, $\$ 5,544$. This experiment implies a rise in the black-white wage ratio from $75 \%$ to $102 \%$ and and a rise in the black-white wealth ratio from $40 \%$ to $69 \%$. These results suggest that labor market conditions rather than initial wealth are responsible for the observed differences in labor market performance between blacks and whites, but not fully for the observed racial wealth gap.

\section{Conclusions}

The main purpose of this paper has been to determine the extent to which wealth disparity is responsible for the observed differences in early employment careers of black and white individuals. A utility-maximizing search model is shown to capture the main quantitative features of the data. Through comparative statics experiments, I show that most of the differences in labor market performance between blacks and whites are accounted for by differences in their wage offer distributions and arrival rates. If blacks had the initial wealth distribution of whites, they would experience a modest increase in wages and only at the beginning of their employment careers. 


\section{References}

Altonji, J. G. \& Doraszelski, U. (2001), The Role of Permanent Income and Demographics in Black/White Differences in Wealth. NBER Working Paper 8473.

Blau, F. \& Graham, J. W. (1990), 'Black-White Differences in Wealth and Asset Composition', Quarterly Journal of Economics 105(2), 321-339.

Eckstein, Z. \& Wolpin, K. (1989), 'The specification and estimation of dynamic stochastic discrete choice models', Journal of Human Resources 24, 562-598.

Fairlie, R. W. (1999), 'The Absence of the African-American Owned Business: An Analysis of the Dynamics of Self-Employment', Economic Inquiry 17(1), 80-108.

Fairlie, R. W. \& Meyer, B. D. (2000), 'Ethnic and Racial Self-employment Differences and Possible Explanations', Journal of Human Resources 35(4), 543-669.

Gittleman, M. \& Wolff, E. N. (2003), 'Racial Disparities in Patterns of Wealth Accumulation', Journal of IIuman Resources (forthcoming).

Jianakoplos, N. A., Menchik, P. L. \& Irvine, F. O. (1989), Using panel data to assess the bias in cross-sectional inferences of life-cycle changes in the level and composition of household wealth, in R. Lipsey \& H. S. Tice, eds, 'The Measurement of Saving, Investment and Wealth', The University of Chicago Press, Chicago, pp. 553-644.

Menchik, P. L. \& Jianakoplos, N. A. (1997), 'Black-White Wealth Inequality. Is Inheritance the Reason?', Economic Inquiry 35, 428-442.

Neal, D. A. \& Johnson, W. R. (1996), 'The Role of Pre-market Factors in Black/White Wage Differences', Journal of Political Economy 104(5), 869-895.

Oliver, M. L. \& Shapiro, T. M. (1997), Black Wealth/White Wealth: A New Perspective on Racial Inequality, Routledge, London.

Rendon, S. (2002), Job Search and Asset Accumulation under Borrowing Constraints. Universidad Carlos III. mimeo.

Rust, J. (1988), 'Maximum likelihood estimation of discrete control processes', SIAM Control and Optimization 26(5), 1006-1024.

Smith, J. P. (1995), 'Racial and Ethnic Differences in Wealth in the Health and Retirement Study', Journal of Human Resources 30(Supplement), S158-S183.

Smith, J. P. \& Welch, F. R. (1989), 'Black Economic Progress after Myrdal', Journal of Economic Literature 27(2), 519-564.

Wolff, E. (1994), 'Trends in Household Wealth in the United States: 1962-1963 and 1983-1989', Journal of Income and Wealth 40(2), 143-174. 
Wolpin, K. (1992), 'The determinants of black-white differences in early employment careers: Search, layoffs, quits, and endogeneous wage', Journal of Political Economy 100, 535-560. 
Table 1: Unemployment, Wealth and Wages by Years after Graduation. White and Black Male High School Graduates (amounts in 1985 dollars)

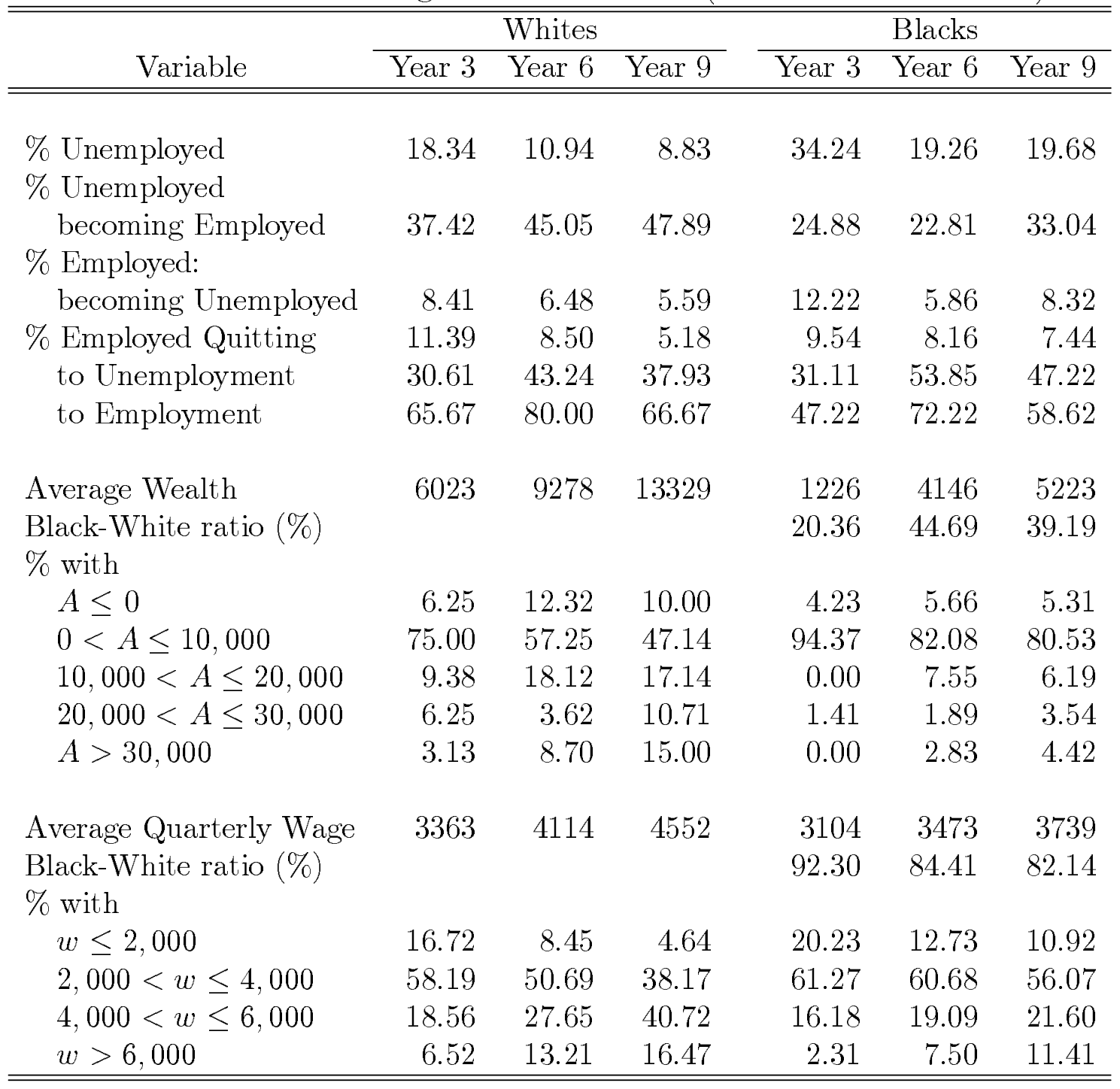


Table 2: Composition of Net Wealth by Wealth level and Years after Graduation

\begin{tabular}{|c|c|c|c|c|c|c|c|c|}
\hline & \multicolumn{4}{|c|}{ Whites } & \multicolumn{4}{|c|}{ Blacks } \\
\hline & $0-10$ & $10-20$ & $20-30$ & +30 & $0-10$ & $10-20$ & $20-30$ & +30 \\
\hline Years $\leq 6$ & & & & & & & & \\
\hline Residential & 7 & 17 & 24 & 23 & 2 & 22 & 39 & 15 \\
\hline Financial & 24 & 19 & 15 & 19 & 25 & 13 & 30 & 49 \\
\hline Business & 5 & 5 & 14 & 42 & 1 & 5 & 8 & 0 \\
\hline Vehicles & 50 & 33 & 33 & 6 & 51 & 42 & 10 & 14 \\
\hline Other & 14 & 25 & 15 & 10 & 18 & 28 & 12 & 23 \\
\hline Years $>6$ & & & & & & & & \\
\hline Residential & 16 & 31 & 32 & 26 & 8 & 29 & 30 & 39 \\
\hline Financial & 22 & 19 & 21 & 39 & 19 & 18 & 20 & 37 \\
\hline Business & 5 & 3 & 4 & 22 & 1 & 2 & 4 & 23 \\
\hline Vehicles & 53 & 29 & 26 & 7 & 49 & 28 & 24 & 6 \\
\hline Other & 4 & 18 & 17 & 6 & 24 & 23 & 22 & 6 \\
\hline
\end{tabular}

Table 3: Average Wealth by Wages and Years after Graduation in 1985 dollars

\begin{tabular}{lrrrrr}
\hline \hline \multirow{2}{*}{ Wages } & \multicolumn{2}{c}{ Whites } & & \multicolumn{2}{c}{ Blacks } \\
\cline { 2 - 3 } & Years $\leq 6$ & Years $>6$ & & Years $\leq 6$ & Years $>6$ \\
\hline$\leq 2,000$ & 1368 & 2940 & & 730 & 1933 \\
$2,000<w \leq 4,000$ & 5453 & 9178 & & 2273 & 3188 \\
$4,000<w \leq 6,000$ & 8508 & 13766 & & 4699 & 8592 \\
$w>6,000$ & 8744 & 15178 & & 6115 & 10335 \\
\hline \hline
\end{tabular}


Table 4: Parameter Estimates and Asymptotic Standard Errors

\begin{tabular}{rrrrrrr}
\hline \hline & \multicolumn{2}{c}{ Whites } & & \multicolumn{2}{c}{ Blacks } \\
\cline { 2 - 3 } \cline { 5 - 6 }$\Theta$ & Estimates & $($ ASE $)$ & & Estimates & $($ ASE $)$ \\
\hline \hline$b$ & 398.31 & $(50.03)$ & & 494.14 & $(77.49)$ \\
$\lambda_{u}$ & 0.932635 & $(0.078587)$ & & 0.838318 & $(0.016471)$ \\
$\lambda_{e}$ & 0.132450 & $(0.026429)$ & & 0.161893 & $(0.069360)$ \\
$\theta$ & 0.044196 & $(0.010314)$ & & 0.053863 & $(0.022409)$ \\
$\mu$ & 7.171731 & $(0.051495)$ & & 7.093364 & $(0.029809)$ \\
$\sigma$ & 0.978521 & $(0.078744)$ & & 0.775161 & $(0.010701)$ \\
$\gamma$ & 1.309576 & $(0.142095)$ & & 1.099607 & $(0.349032)$ \\
$s$ & 0.107575 & $(0.014880)$ & & 0.191506 & $(0.030502)$ \\
$\sigma_{A}$ & 16179.24 & $(584.88)$ & & 10245.36 & $(255.71)$ \\
$\sigma_{w}$ & 0.578676 & $(0.015361)$ & & 0.581876 & $(0.016204)$ \\
$-\ln \mathcal{L}$ & \multicolumn{2}{c}{5750.58} & & \multicolumn{2}{c}{4664.58} \\
Nobs & \multicolumn{2}{c}{212} & & \multicolumn{2}{c}{158} \\
\hline \hline
\end{tabular}


Table 5: Summary. Whites: Actual and Predicted Choice Distribution (\%):

All Variables for three selected Years after Graduation

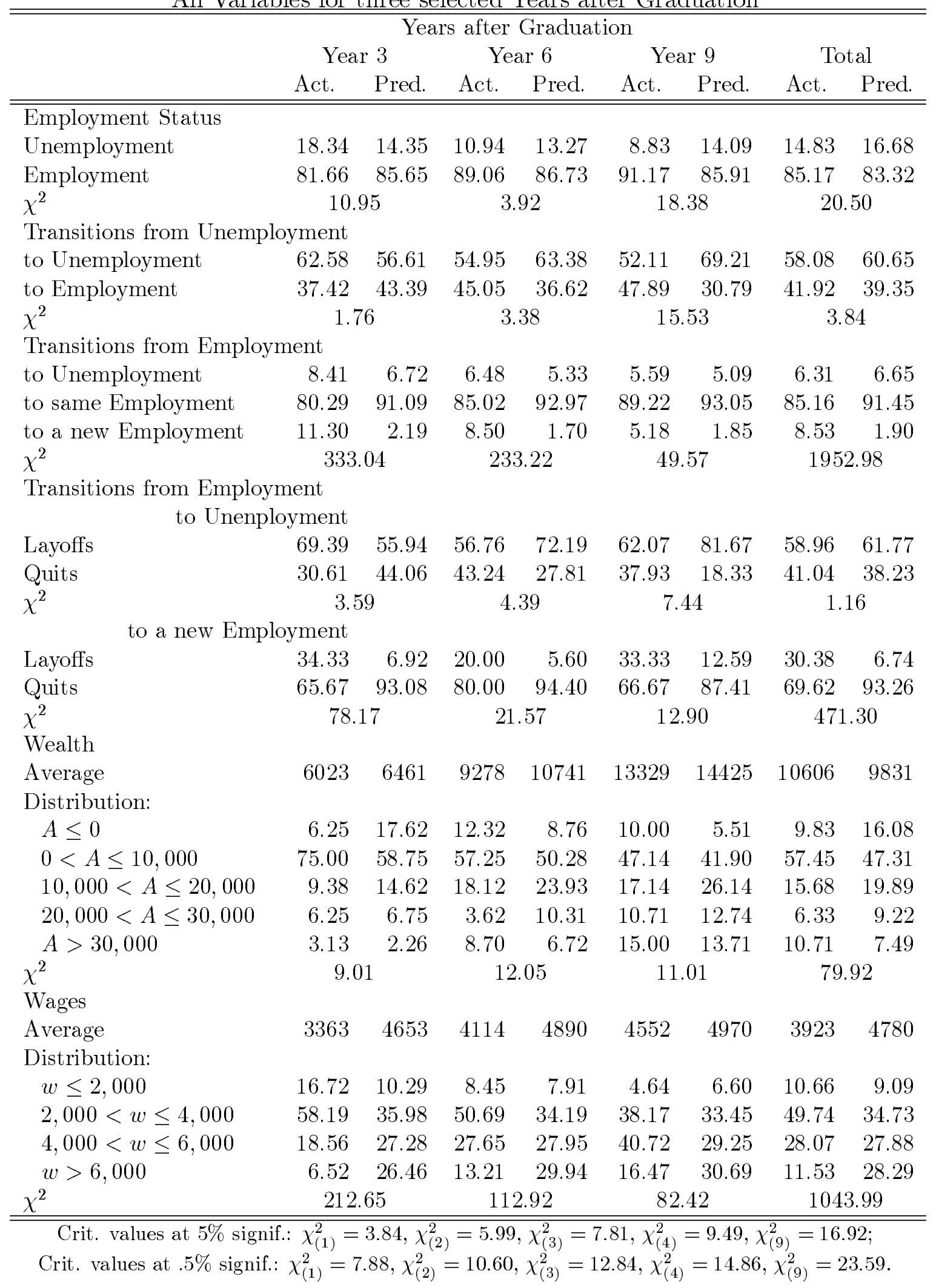


Table 6: Summary. Blacks: Actual and Predicted Choice Distribution (\%): All Variables for three selected Years after Graduation

\begin{tabular}{|c|c|c|c|c|c|c|c|c|}
\hline & \multicolumn{6}{|c|}{ Years after Graduation } & \multirow{2}{*}{\multicolumn{2}{|c|}{ Total }} \\
\hline & \multicolumn{2}{|c|}{ Year 3} & \multicolumn{2}{|c|}{ Year 6} & \multicolumn{2}{|c|}{ Year 9} & & \\
\hline & Act. & Pred. & Act. & Pred. & Act. & Pred. & Act. & Pred. \\
\hline \multicolumn{9}{|l|}{ Employment Status } \\
\hline Unemployment & 34.24 & 17.20 & 19.26 & 16.95 & 19.68 & 14.45 & 28.19 & 19.74 \\
\hline Employment & 65.76 & 82.80 & 80.74 & 83.05 & 80.32 & 85.55 & 71.81 & 80.26 \\
\hline$\chi^{2}$ & \multicolumn{2}{|c|}{126.89} & \multicolumn{2}{|c|}{2.25} & \multicolumn{2}{|c|}{12.63} & \multicolumn{2}{|c|}{268.37} \\
\hline \multicolumn{9}{|c|}{ Transitions from Unemployment } \\
\hline to Unemployment & 75.12 & 63.48 & 77.19 & 66.48 & 66.96 & 66.70 & 73.05 & 65.70 \\
\hline to Employment & 24.88 & 36.52 & 22.81 & 33.52 & 33.04 & 33.30 & 26.95 & 34.30 \\
\hline$\chi^{2}$ & \multicolumn{2}{|c|}{6.25} & \multicolumn{2}{|c|}{5.17} & \multicolumn{2}{|c|}{0.00} & \multicolumn{2}{|c|}{28.20} \\
\hline \multicolumn{9}{|c|}{ Transitions from Employment } \\
\hline to Unemployment & 12.22 & 6.69 & 5.86 & 6.53 & 8.32 & 5.88 & 9.43 & 6.79 \\
\hline to same Employment & 78.24 & 90.64 & 85.98 & 91.27 & 84.25 & 91.90 & 81.74 & 90.72 \\
\hline to a new Employment & 9.54 & 2.68 & 8.16 & 2.19 & 7.44 & 2.22 & 8.83 & 2.49 \\
\hline$\chi^{2}$ & \multicolumn{2}{|c|}{141.75} & \multicolumn{2}{|c|}{98.10} & \multicolumn{2}{|c|}{77.88} & \multicolumn{2}{|c|}{1056.40} \\
\hline \multicolumn{9}{|c|}{$\begin{array}{l}\text { Transitions from Employment } \\
\text { to Unemployment }\end{array}$} \\
\hline Layoffs & 68.89 & 80.00 & 46.15 & 82.51 & 52.78 & 86.79 & 57.53 & 78.04 \\
\hline Quits & 31.11 & 20.00 & 53.85 & 17.49 & 47.22 & 13.21 & 42.47 & 21.96 \\
\hline$\chi^{2}$ & 3.4 & & & 81 & & 34 & & 29 \\
\hline to a new Emp & loyment & & & & & & & \\
\hline Layoffs & 52.78 & 10.00 & 27.78 & 13.91 & 41.38 & 7.50 & 38.74 & 10.41 \\
\hline Quits & 47.22 & 90.00 & 72.22 & 86.09 & 58.62 & 92.50 & 61.26 & 89.59 \\
\hline$\chi^{2}$ & 73. & & & 78 & & 98 & & 32 \\
\hline Wealth & & & & & & & & \\
\hline Average & 1226 & 1763 & 4146 & 3522 & 5223 & 5271 & 4000 & 3350 \\
\hline Black-White ratio (\%) & 20.36 & 27.29 & 44.69 & 32.79 & 39.19 & 36.54 & 37.71 & 34.08 \\
\hline Distribution: & & & & & & & & \\
\hline$A \leq 0$ & 4.23 & 58.02 & 5.66 & 44.26 & 5.31 & 38.35 & 5.69 & 49.04 \\
\hline $0<A \leq 10,000$ & 94.37 & 28.91 & 82.08 & 38.77 & 80.53 & 39.45 & 83.39 & 33.77 \\
\hline $10,000<A \leq 20,000$ & 0.00 & 7.90 & 7.55 & 11.55 & 6.19 & 12.47 & 5.69 & 10.01 \\
\hline $20,000<A \leq 30,000$ & 1.41 & 3.86 & 1.89 & 3.50 & 3.54 & 5.35 & 1.93 & 4.16 \\
\hline$A>30,000$ & 0.00 & 1.31 & 2.83 & 1.93 & 4.42 & 4.38 & 3.30 & 3.02 \\
\hline$\chi^{2}$ & 148 & & & 67 & & 78 & 100 & 4.63 \\
\hline Wages & & & & & & & & \\
\hline Average & 3104 & 4064 & 3473 & 4164 & 3739 & 4170 & 3384 & 4084 \\
\hline Black-White ratio (\%) & 92.30 & 87.34 & 84.41 & 85.15 & 82.14 & 83.90 & 86.26 & 85.44 \\
\hline Distribution & & & & & & & & \\
\hline$w \leq 2,000$ & 20.23 & 17.06 & 12.73 & 14.78 & 10.92 & 14.87 & 14.57 & 16.19 \\
\hline $2,000<w \leq 4,000$ & 61.27 & 40.84 & 60.68 & 40.96 & 56.07 & 41.06 & 60.27 & 41.22 \\
\hline $4,000<w \leq 6,000$ & 16.18 & 23.66 & 19.09 & 24.23 & 21.60 & 24.49 & 18.58 & 23.89 \\
\hline$w>6,000$ & 2.31 & 18.44 & 7.50 & 20.02 & 11.41 & 19.59 & 6.58 & 18.70 \\
\hline$\chi^{2}$ & 94. & & & 30 & & 39 & 68 & .94 \\
\hline
\end{tabular}


Table 7: Policy Experiments

\begin{tabular}{|c|c|c|c|c|}
\hline & \multirow[t]{2}{*}{$\begin{array}{c}\text { Prediction } \\
\text { Blacks }\end{array}$} & \multicolumn{2}{|c|}{$\begin{array}{c}\text { Counterfactuals } \\
\text { Blacks's with whites' }\end{array}$} & \multirow[t]{2}{*}{$\begin{array}{c}\text { Prediction } \\
\text { Whites }\end{array}$} \\
\hline & & $\begin{array}{c}p\left(A_{0}\right), \\
s\end{array}$ & $\begin{array}{c}\lambda_{u}, \lambda_{e}, \theta \\
\mu, \sigma\end{array}$ & \\
\hline & \multicolumn{4}{|c|}{ First unemployment spell } \\
\hline Duration of unemployment & 2.98 & 2.91 & 2.88 & 2.40 \\
\hline First accepted wage & 3324 & 3300 & 4340 & 3925 \\
\hline \multirow[t]{2}{*}{ Black-White ratio \% } & 84.69 & 84.07 & 110.57 & 100.00 \\
\hline & \multicolumn{4}{|c|}{ 1st Quarter after Graduation } \\
\hline Unemployment rate (\%) & 68.67 & 69.62 & 67.78 & 54.48 \\
\hline Wealth & 3311 & 4734 & 3311 & 5325 \\
\hline Black-White ratio \% & 62.18 & 88.90 & 62.18 & 100.00 \\
\hline Wages & 3286 & 3354 & 4322 & 3843 \\
\hline Black-White & 85.51 & 87.28 & 112.46 & 100.00 \\
\hline Consumption & 2410 & 2356 & 2852 & 2682 \\
\hline \multirow[t]{2}{*}{ Black-White ratio \% } & 90.23 & 87.84 & 106.34 & 100.00 \\
\hline & \multicolumn{4}{|c|}{ 10th Quarter after Graduation } \\
\hline Unemploym & 17.41 & 17.53 & 16.01 & 14.39 \\
\hline Wealth & 1679 & 3666 & 2758 & 6247 \\
\hline Black-White ratio \% & 26.88 & 58.68 & 44.15 & 100.00 \\
\hline Wages & 3880 & 3838 & 5172 & 4839 \\
\hline Black-White ratio \% & 80.18 & 79.31 & 106.88 & 100.00 \\
\hline Consumption & 3165 & 3148 & 4126 & 3907 \\
\hline \multirow[t]{2}{*}{ Black-White ratio \% } & 81.01 & 80.57 & 105.60 & 100.00 \\
\hline & \multicolumn{4}{|c|}{ 20th Quarter after Graduation } \\
\hline Unemployment rate (\%) & 16.01 & 16.27 & 14.75 & 14.48 \\
\hline Wealth & 3210 & 5249 & 5787 & 9991 \\
\hline Black-White ratio \% & 32.13 & 52.54 & 57.92 & 100.00 \\
\hline Wages & 4056 & 4047 & 5435 & 5206 \\
\hline Black-White ratio \% & 77.91 & 77.73 & 104.40 & 100.00 \\
\hline Consumption & 3401 & 3404 & 4541 & 4381 \\
\hline \multirow[t]{2}{*}{ Black-White ratio \% } & 77.63 & 77.70 & 103.65 & 100.00 \\
\hline & \multicolumn{4}{|c|}{ 40th Quarter after Graduation } \\
\hline Unemployment rate (\%) & 17.28 & 17.28 & 15.25 & 14.58 \\
\hline Wealth & 6415 & 8435 & 11189 & 16131 \\
\hline Black-White ratio \% & 39.77 & 52.29 & 69.36 & 100.00 \\
\hline Wages & 4176 & 4165 & 5633 & 5544 \\
\hline Black-White ratio \% & 75.33 & 75.13 & 101.61 & 100.00 \\
\hline Consumption & 3453 & 3497 & 4699 & 4688 \\
\hline Black-White ratio \% & 73.66 & 74.60 & 100.24 & 100.00 \\
\hline
\end{tabular}




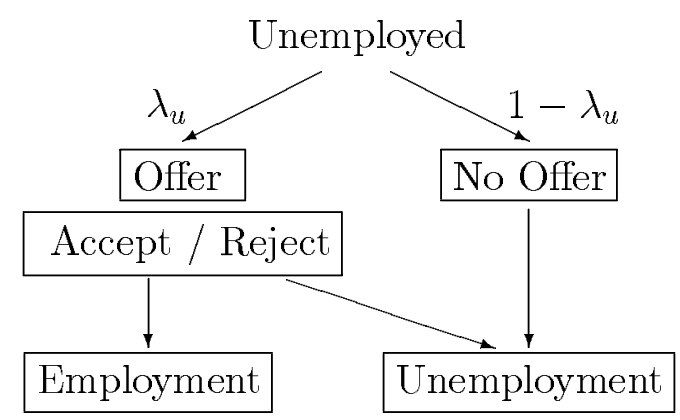

Figure 1: Transitions from Unemployment

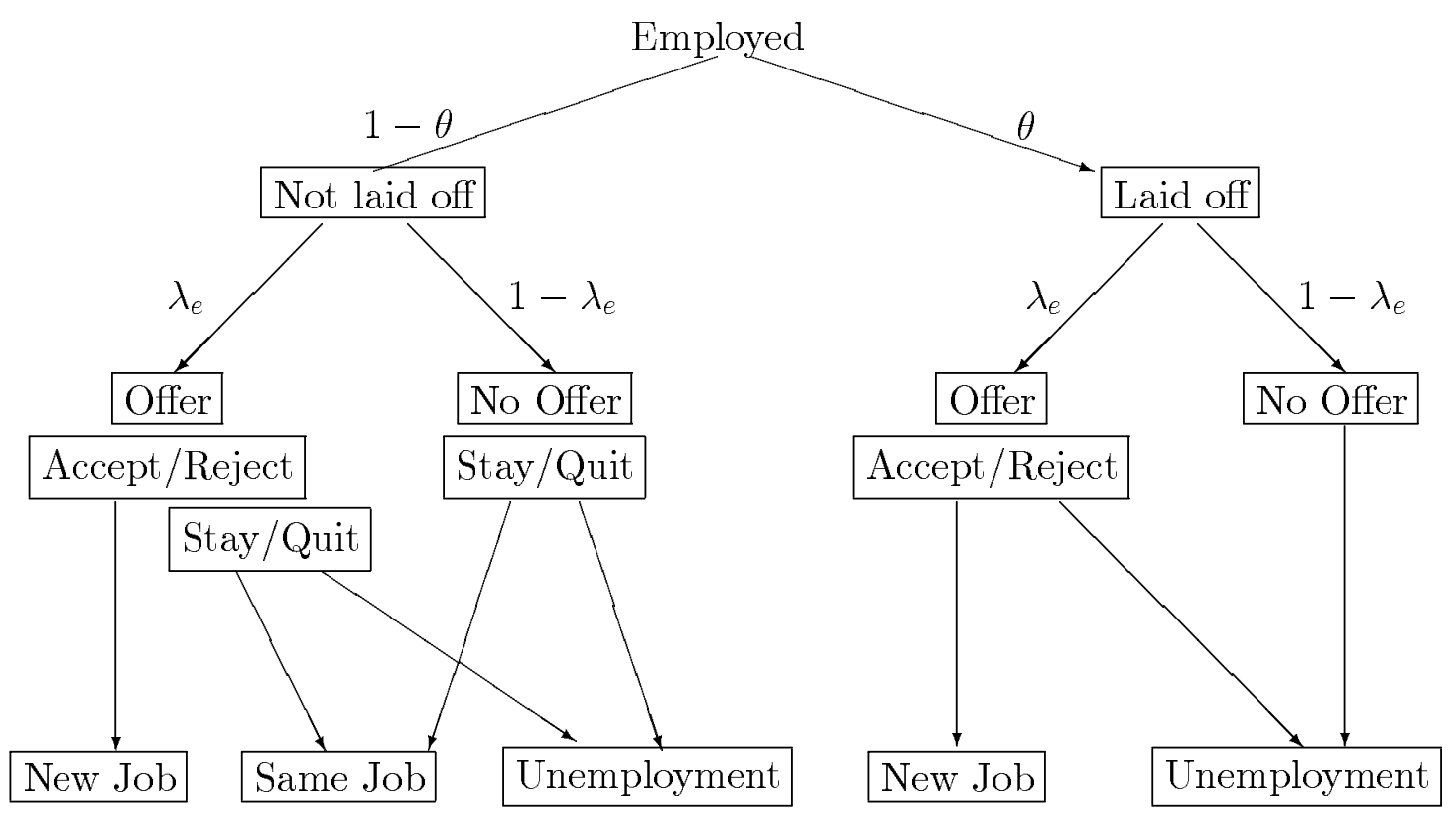

Figure 2: Transitions from Employment 


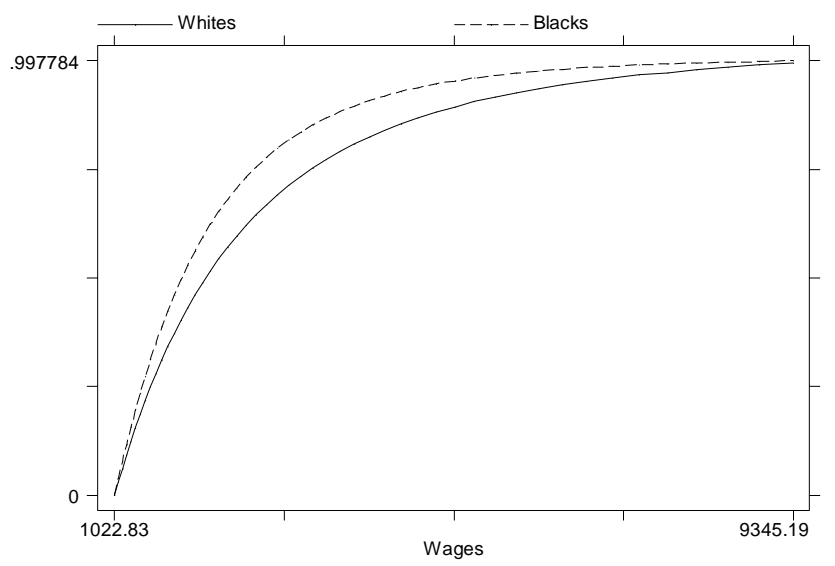

Figure 3: Wage Offer Distribution $F(w)$

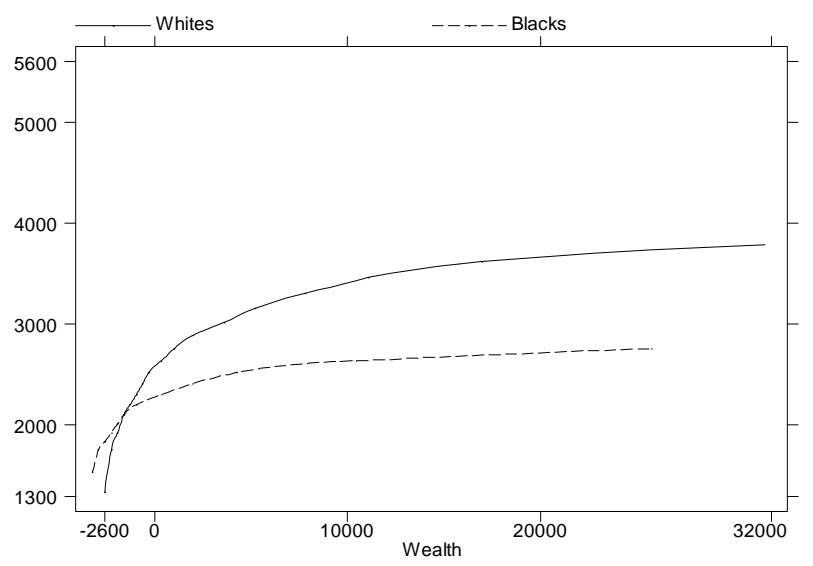

Figure 4: Reservation Wage $w^{*}(A)$

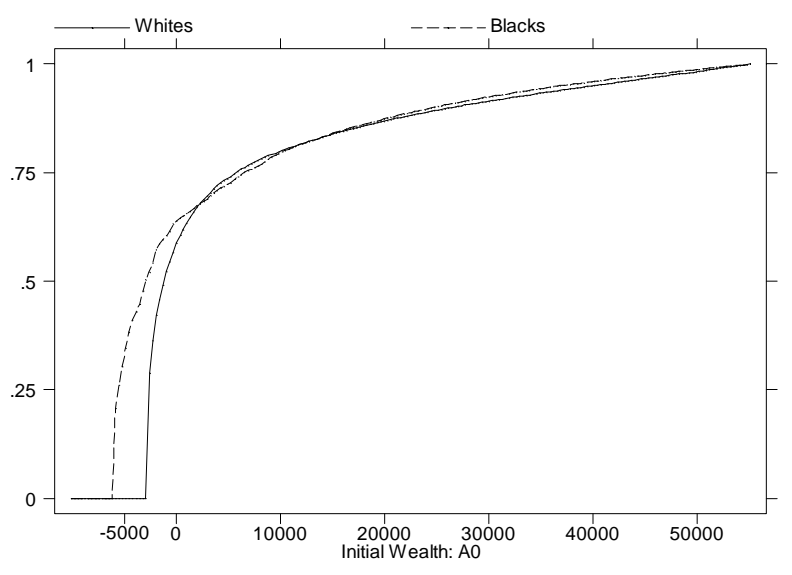

Figure 5: Initial Wealth Distribution $P\left(A_{\mathbf{0}}\right)$ 


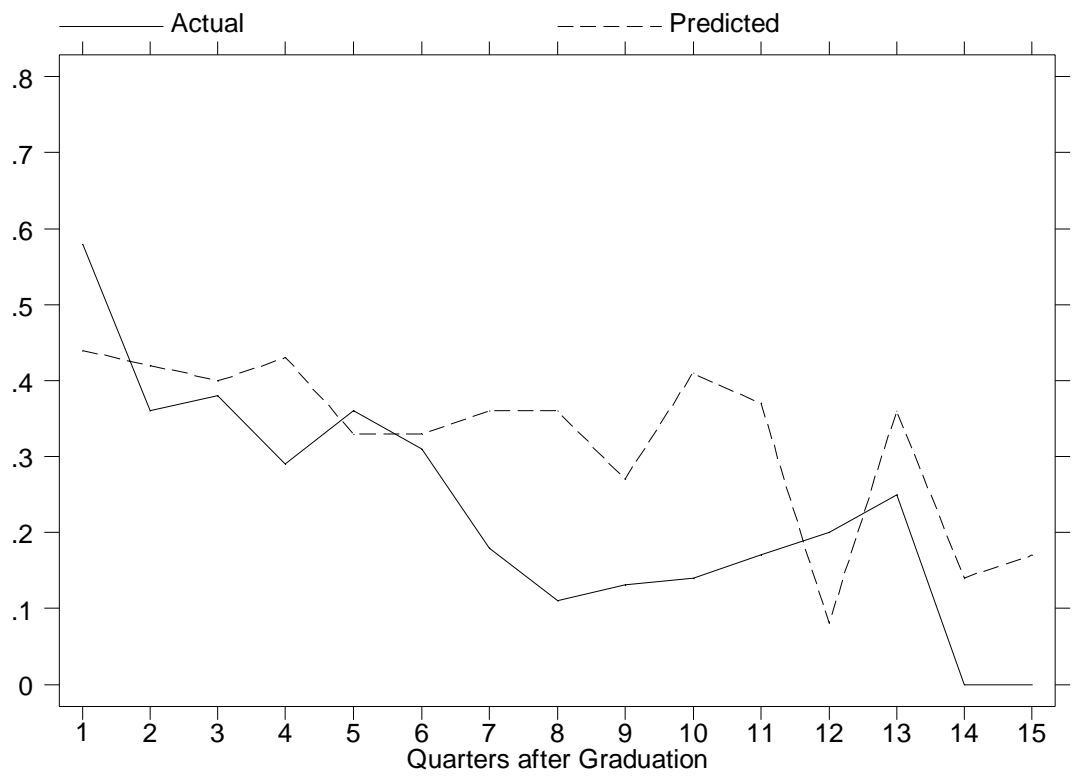

Figure 6: Whites' Hazard Rates: First Unemployment Spell

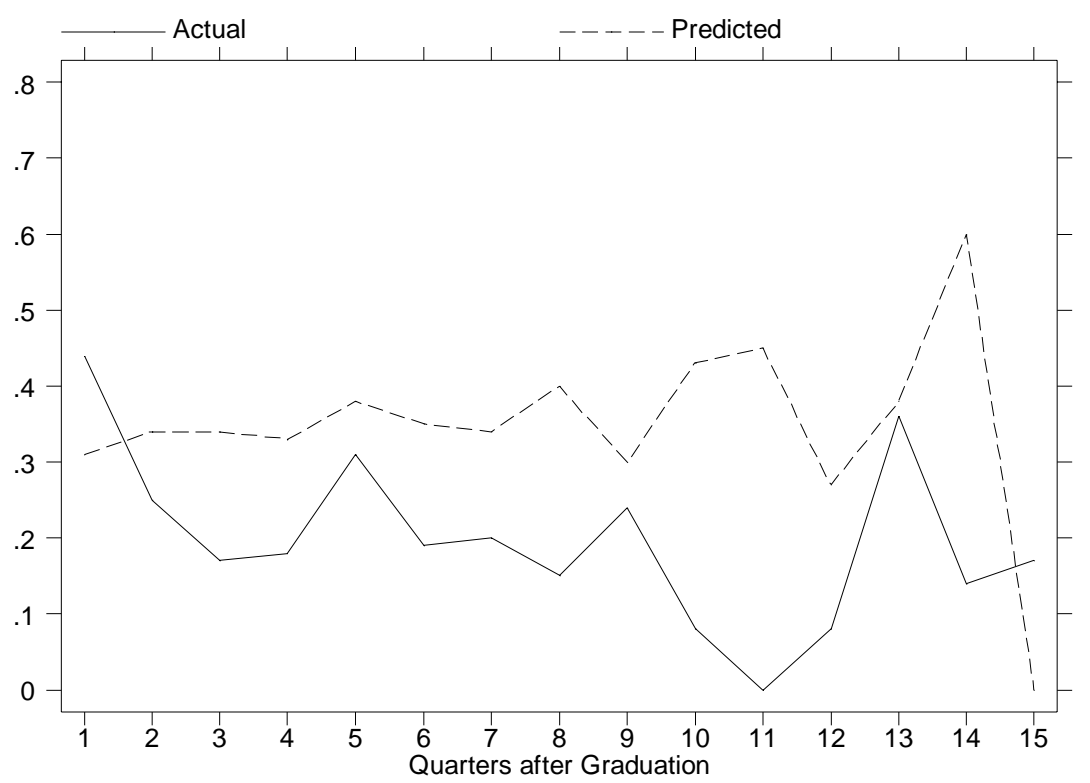

Figure 7: Blacks' Hazard Rates: First Unemployment Spell 


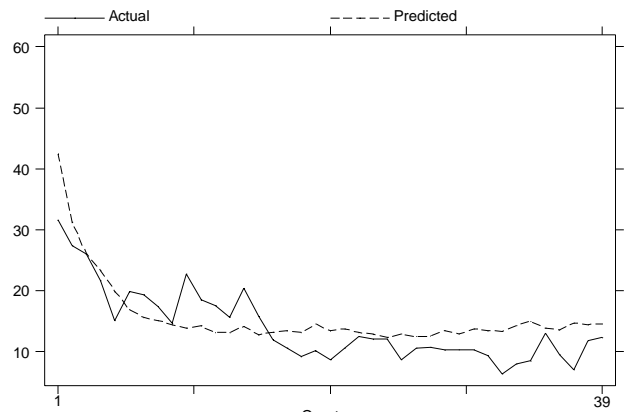

8a: Unemployment Rate by Quarter after Graduation. Whites

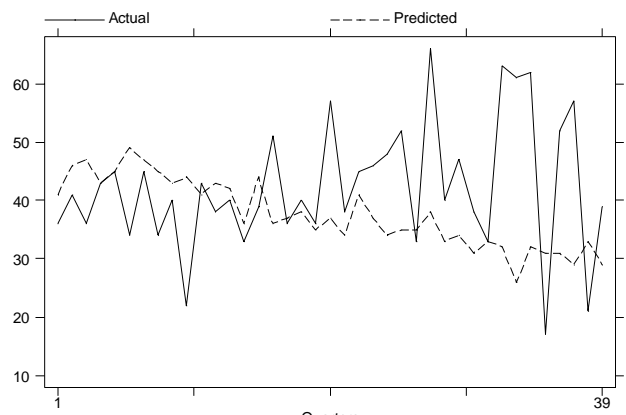

8c: Transition: Unemployment to Employment. Whites

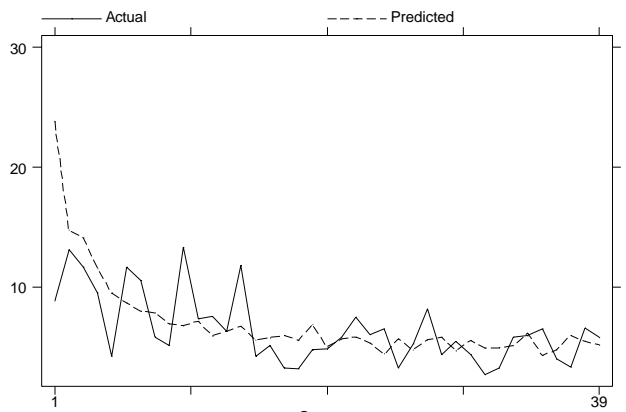

8e: Transition: Employment to Unemployment. Whites

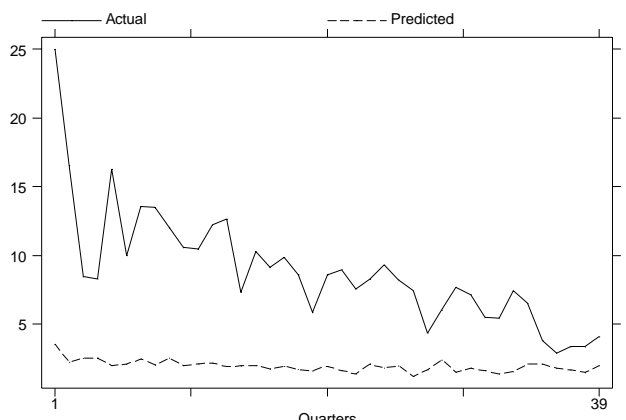

8g: Transition: Employment Change. Whites

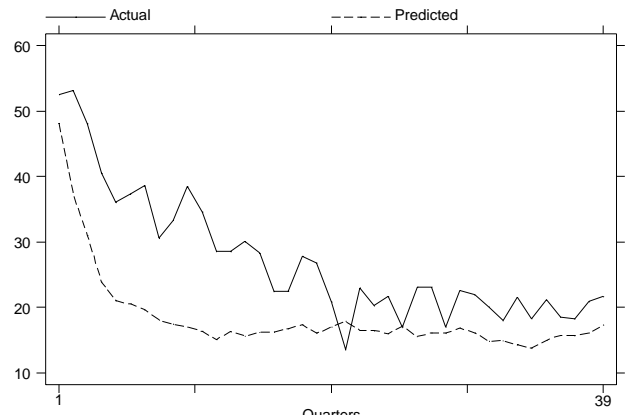

8b: Unemployment Rate by Quarter after Graduation. Blacks

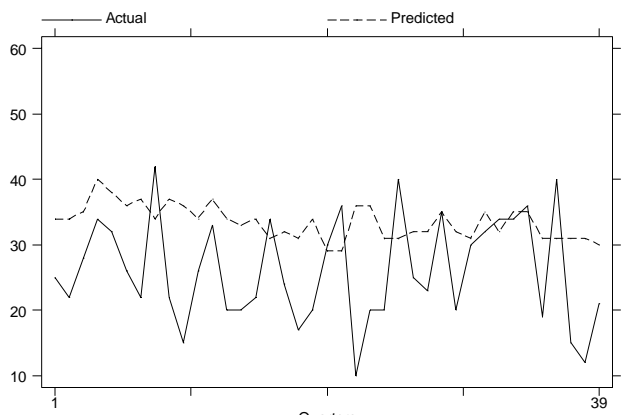

8d: Transition: Unemployment to Employment. Blacks

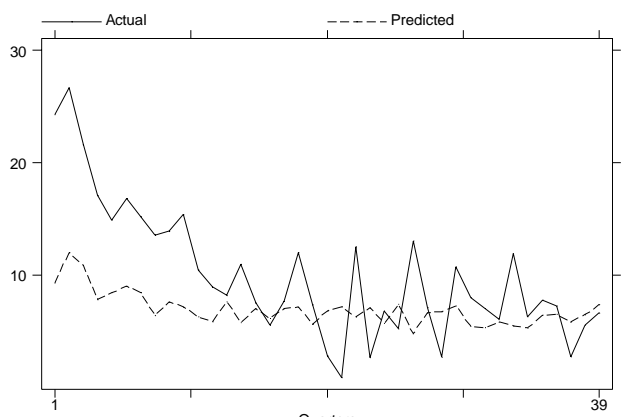

8f: Transition: Employment to Unerters

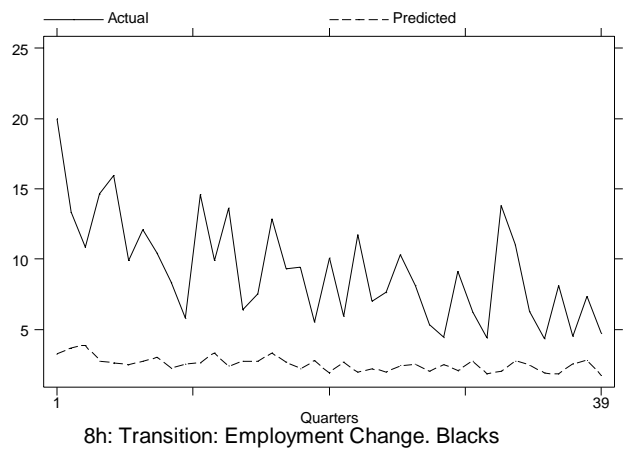

Figure 8: Actual and Predicted Paths by Race Group:

Employment Status and Employment Transitions 

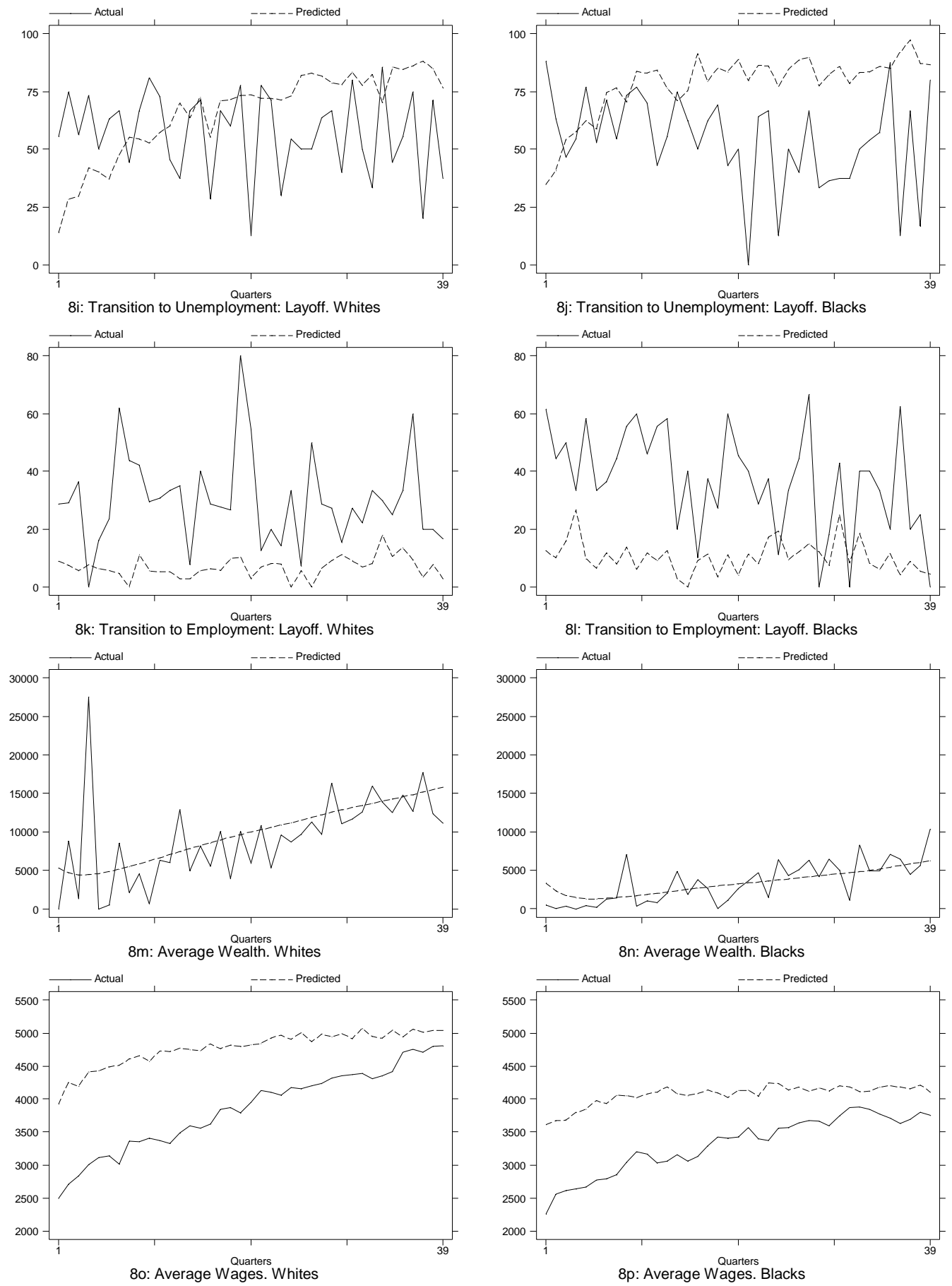

Figure 8 (cont): Actual and Predicted Paths by Race Group:

Layoffs, Wealth, and Wages 